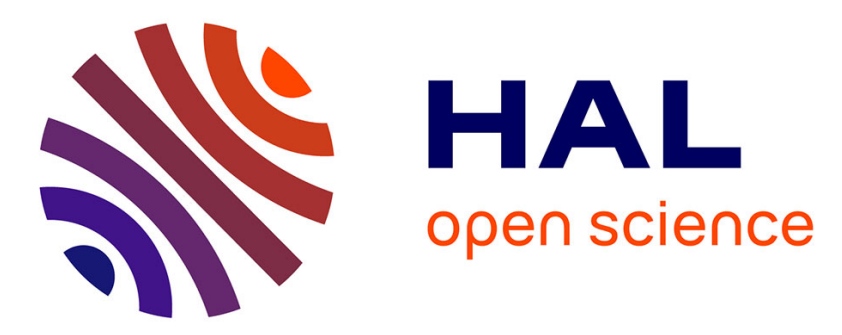

\title{
Agroecology publications and coloniality of knowledge
}

Luis Gómez, Leonardo Ríos-Osorio, María Eschenhagen

\section{To cite this version:}

Luis Gómez, Leonardo Ríos-Osorio, María Eschenhagen. Agroecology publications and coloniality of knowledge. Agronomy for Sustainable Development, 2013, 33 (2), pp.355-362. 10.1007/s13593-0120109-6 . hal-01201353

\section{HAL Id: hal-01201353 \\ https://hal.science/hal-01201353}

Submitted on 17 Sep 2015

HAL is a multi-disciplinary open access archive for the deposit and dissemination of scientific research documents, whether they are published or not. The documents may come from teaching and research institutions in France or abroad, or from public or private research centers.
L'archive ouverte pluridisciplinaire HAL, est destinée au dépôt et à la diffusion de documents scientifiques de niveau recherche, publiés ou non, émanant des établissements d'enseignement et de recherche français ou étrangers, des laboratoires publics ou privés. 


\title{
Agroecology publications and coloniality of knowledge
}

\author{
Luis Fernando Gómez • Leonardo Ríos-Osorio • \\ María Luisa Eschenhagen
}

Accepted: 31 July 2012 /Published online: 6 September 2012

(C) INRA and Springer-Verlag, France 2012

\begin{abstract}
Agroecology is a recent scientific field that has become increasingly active since 1990 . It has moved away from conventional emphasis on crops and productivity and has embraced a systemic, multidisciplinary approach that focuses on agroecosystems or food systems and their sustainability. Here, we analyze original articles in agroecology that have been published in eight major global databases in order to establish where agroecology is taking place and what topics focus on agroecology. For this, a systematic review was conducted with original articles with the word "agroecological" in the title and published in English, Spanish, and/or Portuguese as inclusion criteria. One hundred thirty-one articles were found but we were able to access 116. Area of study, country of affiliation of the researchers, publication countries, and topic of the paper were analyzed. It was found that Brazil (18 articles out of 131), Cuba (8), and Nigeria (8) are the most studied countries; Brazil (19 in 116 articles), the USA (12), and Cuba (9) are the countries with more affiliated researchers; and the Netherlands (26 out of 131), Brazil (19), and Germany (12) are the countries that publish articles the most. Additionally, it was found that the most popular topics of research are behavior of crops and species in function of environmental
\end{abstract}

L. F. Gómez $(\bowtie) \cdot$ L. Ríos-Osorio

Program of Agroecology, Universidad de Antioquia,

Ciudad Universitaria, Calle 67 No. 53-108, Bloque 5, oficina 134,

Medellin, Colombia

e-mail: lgomeze77@yahoo.com.co

L. Ríos-Osorio

e-mail:mleonardo@udea.edu.co

M. L. Eschenhagen

Group of Territory, School of Social Sciences,

Universidad Pontificia Bolivariana,

Circular 1 \#70-01, Bloque 7, oficina 411,

Medellin, Colombia

mariesche22@gmail.com conditions (15 out of 116), soils (12), and production in agroecological systems (13), while sustainability (3), agroecological transition (1), and biodiversity (1) are rare. Our findings show that research follows a colonial pattern where industrialized countries lead publishing, conduct research studies both in industrialized and non-industrialized countries, and do not publish in non-industrialized countries, while nonindustrialized countries publish in industrialized and nonindustrialized countries and do not conduct research studies in foreign regions. In addition, they show that food systems and sustainability are still not common subjects of study although they are main concerns in agroecology.

Keywords Agroecology - Coloniality of knowledge · Global databases $\cdot$ Sustainability $\cdot$ Food systems

\section{Introduction}

Industrialized or conventional agriculture was globally embraced as a means to both meet food demands of a rapidly growing human population and achieve economic growth in developing countries in the late 1960s and early 1970s. However, it brought serious negative side effects such as nutrient loss in soils, deforestation, and pollution, while rural populations did not get out of poverty (González 1992; Pereira 2008). As a result, several scholars from the early 1980s started promoting agroecology as an alternative to conventional agriculture which could restrain environmental degradation due to food production and promote sustainable development (Altieri and Yurjevic 1991). Nevertheless, there has not been a consensus on the definition of this science, its scope, and its study object which poses a question on what agroecology is actually studying, and little is known about what the dynamics of empirical research in agroecology are like. 
Currently, there are three main definitions of agroecology as a scientific discipline. One, predominantly applied in Germany, describes agroecology as agroecosystems ecology. This approach places agroecology as an area of classical ecology, restricting it to the study of biophysical relations where humans are basically put aside (Wezel et al. 2009). A second definition focuses on the sustainability of agroecosystems, taking into account human and nonhuman interactions (Sevilla 2006; Altieri 2010). Last, a more recent definition has been proposed by Francis et al. (2003) which shifts from agroecosystems to food systems, widening the scope of the second characterization to include distribution and consumption of agricultural products. However, these definitions have common epistemological bases that depart from the ones of conventional science. For instance, they adopt a systems thinking approach which have become a pivotal epistemological base in ecology (Midgley 1993), and several authors highlight agroecology as a nondisciplinary approach (Dalgaard et al. 2003; Altieri 2010).

On the other hand, the problems of definition, scope, and history of agroecology have been the main subject of most of the reviews that have been published since the consolidation of agroecology as a scientific practice (Hecht 1995; Wezel et al. 2009; Altieri 2010; Tomich et al. 2011), limiting their analysis essentially to theoretical, reflection, and review articles, as well as books and book chapters. Only Wezel et al. (2009) and Wezel and Soldat (2009) include original articles, and the latter does a topic and geopolitical analysis of publications but does not limit it to original articles and does not study relevant factors as country of publication or country where the studies were conducted. The present review aims at analyzing the geopolitical and topic distribution of agroecological empirical research since the 1990s, when agroecology consolidated, based on the major subscription databases and AGRIS, FAO's global public domain database.

\section{Materials and methods}

The collection of articles was carried out by a method of systematic review modified from the one proposed by Pai et al. (2004), between September 20 and September 28, 2011. The focused review question was what has been published on agroecological empirical research in academic databases used worldwide since 1990, and the main inclusion criteria were original articles-i.e., scientific articles where authors present empirical studies and show their results for the first time - with the word agroecological in the title and published in English, Spanish, and Portuguese. Since the search involved original articles published in Spanish and Portuguese, it was also conducted with the translation of agroecological, allowing for the declension of this adjective in these languages. In addition, hyphenated spellings of the search term in the three languages were discarded because we consider that an analysis of the use of two spellings would be necessary and that is beyond the aim of this research.

The search was carried out in eight databases: Academic Search Complete, AGRIS, Blackwell Sinergy, JSTOR, ScienceDirect, SpringerLink, Taylor \& Francis, and WilsonWeb. When the database allowed it, field- and/or document-type filters were used. Then a manual search of the articles found was done in order to exclude such documents that were not original papers. This was done by selecting only those articles that had an IMRAD structureintroduction, methodology, results, and discussion — or variations of it. After that, citations for all articles remaining were exported to Endnote Web and duplicates were deleted.

\section{Results and discussion}

From 1990 to September 28 of 2011, 131 original articles were found in the databases studied. Since not all databases are repositories, there was no immediate access to all of them. For instance, AGRIS which has information of publications from all around the world does not store any articles and it seldom provides links to websites where material can be downloaded. As a result, it was necessary to search for contact information about authors and journals. After e-mailing the authors - or the journal where the article was published if updated contact information about the authors was not available-116 articles were collected. Information about research and publication could be obtained from the databases, so the actual articles were not necessary, and hence, all the 131 entries were analyzed. Nevertheless, details concerning the authors required the papers, so information was gathered from the 116 articles collected.

\subsection{Research}

All 131 researches published in the databases selected were conducted in 51 countries. Just four of them comprised several countries and two took place in greenhouses or laboratories. The most studied country was Brazil (18), followed by Cuba (8), and Nigeria (8). Bangladesh (7) and Venezuela (5) also counted with good amounts of investigations. On the other hand, there were 22 countries with one research in areas of their territory and 13 with two, summing up $66.7 \%$ of all countries studied.

Although all articles selected included the adjective agroecological in the title, it did not necessarily identify the subject matter. The four most popular topics were behavior of crops/species in function of environmental conditions, 
e.g., climate, soil properties, year, slope (15), soils (14), production in agroecological systems (13), and agroecological practices (12). Phytopathology (seven) and assessment/ implementation of methods - e.g., statistical methods, modeling, and simulation - in agroecology (seven) were also regular topics, whereas sustainability (three), comparative analysis of conventional and agroecological production (three), biodiversity (one), traditional knowledge (one), design of agroecological systems (one), and agroecological transition (one) were not. Several papers dealt livestock (seven), including fish (one), and climate change (four), but there were not any investigations on food systems.

\subsection{Authors}

Articles do not give information about the nationality of the authors but they do about where they work. The 116 original articles we were able to obtain were published by people affiliated to 58 countries. From these, 19 of them included researchers working in Brazil, followed by 12 with authors located in the USA, 9 in Cuba, 8 in Nigeria, and 7 in Germany. Bangladesh, Colombia, and Venezuela had researchers authoring in five articles, while 15 and 27 countries contributed with authors to two and one article, respectively. Conversely, the distribution of papers among authors was quite homogenous, not being any particular habitual authors, reaching 108 main authors. Only two researchers were the main author in three articles, S. Aliu who has been affiliated to Kosovo and Albania, and C.J. Olivo who has worked in Brazil. Likewise, four people main authored two articles: G.O. da Silva and A. Loss, affiliated to Brazil; E.R. Canchila, working in Colombia; and K. Hell who has worked in Benin. The remaining 102 main authors $(87.9 \%)$ performed this role once.

Information on the gender of the researchers was not always attainable. From the 116 original articles acquired, 42 (36.2\%) provided only the authors' last name. Out of 74 left, $42(56.8 \%)$ included female authors and $68(91.9 \%)$ malesix articles were all-female authored. On the contrary, all 116 papers gave information about the sort of affiliation authors had. Ninety articles $(77.6 \%)$ comprised researchers from universities, 49 (42.2\%) from the government, including national academies of science, $16(13.8 \%)$ from NGOs, and 9 (7.6\%) from the corporate world. Regarding funding, 109 researches $(94 \%)$ took public funding while 28 (24.1\%) involved private. The inclusion of the community as author was done in one article, although there are two articles were the affiliation of one of their authors was not clear.

\subsection{Publication}

All 131 papers found in the databases were published in 31 countries. All publications were made by single countries.
Seven countries published $65.6 \%$ : the Netherlands (26), Brazil (19), Germany (12), the USA (10), Cuba (9), the UK (5), and Serbia (5). In contrast, 11 countries were responsible for one article each, amounting to $8.4 \%$ of all publications. Ninety-two $(70.2 \%)$ articles were published in English, 19 (14.5 \%) in Portuguese, 18 (13.7 \%) in Spanish, and 2 in Spanish and English. Germany and the Netherlands being outstanding publishing countries may be explained by the fact that they are the home of Springer and Elsevier, respectively, two major scientific publishing companies. Nevertheless, it shows that some of the most prominent global databases contain journals from a few or a single publishing companies instead of storing scientific publications from all around the world, meaning that globalization in science has not provided equal access to the scientific community for all publishing companies, specially independent or small ones located outside Western Europe and the USA.

Articles were published in 108 journals. Agriculture, Ecosystems \& Environment published the most original articles (five), followed by Eurasian Soil Science (four), and Ciência Rural (three). Eighteen and 87 journals published two and one article, respectively. These journals focused in different fields, albeit the difference between some of them might be confusing. For instance, the two most common areas were agricultural science (19) and agronomy (18). In addition, there were also articles published in agriculture (five) and horticulture (four) journals. There were nine publications in clearly multidisciplinary journals, i.e., publications that cover more than three disparate areas, six in animal husbandry journals, and five in phytosanitary/phytopathology journals. Two articles appeared in sustainable development journals, two in multidisciplinary publications that explicitly dealt with sustainability, and there were no research studies published in journals that focused on food systems. This shows that there still is not a leading agroecology journal in global databases.

The distribution of publications, researchers, and study areas is not symmetric. There are more countries studying (58 in 116 articles) than countries studied (51 in 131 articles) or publishing countries (31 in 131 articles). Most of agroecological empirical research pertains to regions that are not located in the so-called developed world (Fig. 1). This syncs with a trend of mainstream environmentalism deeply rooted in colonial logic and modern constructions of nature where the latter is seen as something external to the Western world or confined to uninhabited wild areas (Haraway 1989; Mendiola 2009). Thus, of all empirical researches found, $9.1 \%$ (12) included studies done in Western Europe or North America while 87 \% (114) involved non-industrialized countries (Fig. 2).

Mobility is asymmetric as well. As shown in Fig. 3, while Western Europeans and US Americans research both their 


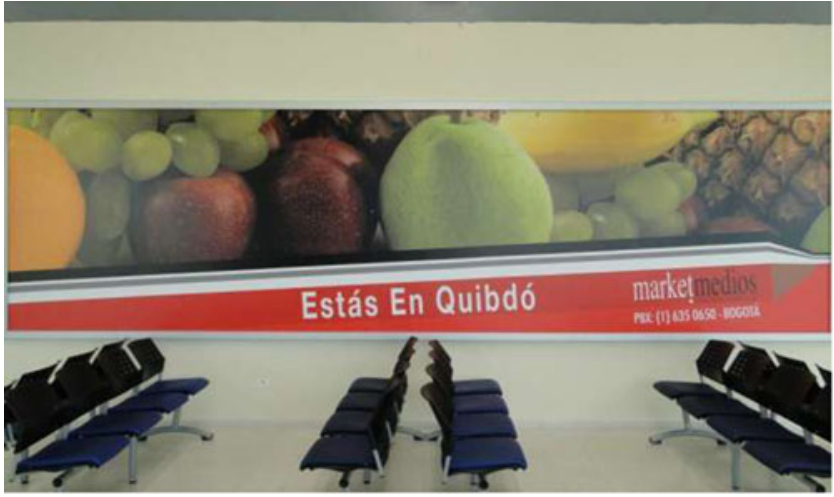

Fig. 1 Choco is a poor region of Colombia where most of the population comprised indigenous and black communities who still live in wild rainforests. Nonetheless, governmental institutions adopt an image of modernity and globalization as seen in this billboard at the region's capital city's airport where globally known foreign fruit are depicted. Picture by Leonardo Ríos-Osorio

own countries as foreign ones, other people tend to study areas in the countries they are affiliated to. Of all 19 researches involving Brazilian authors, 18 were conducted in Brazil and 1 in Costa Rica, a Latin American country. Similarly, there were no researchers working for African universities or institutions that studied areas in industrialized countries. In addition, authors from South Asian institutions researched South Asian regions while Japanese authors (two) participated in South Asian studies, and authors working for Latin American institutions examined areas in Latin America.

There is also a disparity between study areas and researchers and publications in Western Europe and North America. As shown in Fig. 4, they stand out as regions that provide authors $(31 \%$ of articles comprise scholars from these areas, while Latin America, Brazil and Cuba together have researchers in $38.8 \%$ of articles) and publications $(42.7 \%)$, although researches are not carried out there (Fig. 2). For instance, there are as many researchers affiliated to this region as there are to Africa despite studies in the latter (25) more than triple those in the former (8). In addition, Western Europe outnumbers any other region in publishing while only one article was published in Africa.
Likewise, there are more Western European publications (35.1\%) than Latin American (29\%) albeit Brazil and Cuba being the most outstanding countries in research, study areas, and publishing.

English is the preferred publication language (Fig. 5). The amount of articles in Spanish (20) and Portuguese (19) are very similar and remarkably inferior to those in English (94). This shows that in a globalized scholar world, English is the language of agroecological empirical research $(71.8 \%)$ as it has become for science even in social sciences (Ortiz 2009). Portuguese and Spanish keep on being basically domestic languages. Of all 19 articles published in Portuguese, all were published in Brazil and involved Brazilian authors. Similarly, the 16 researches obtained in Spanish were conducted in Spanish speaking countries by Spanish speaking researchers, although one was published in the United States of America, an English speaking country.

Brazil and Cuba are the only two countries with a high number of publications, researchers, and study areas which accords with both the support agroecology has received from the state and the dynamics of science and education in this two countries. Since the collapse of the USSR, the Cuban government has adopted a new agricultural model based on organic agriculture and agroecology (Funes-Monzote 2001). Similarly, the twenty-first century has witnessed a change in the Brazilian government's vision of sustainable agriculture that embraces the principles of agroecology (Caporal 2006). On the other hand, science has been on the rise in Brazil and it has had a pivotal role in Cuban society since the revolution, to the point that it has been considered a key element in society by the Cuban government (Simeón 1997). In Brazil, the amount of scientists, scientific research, and government investment in science have increased abruptly in recent years (Meis et al. 2003; Regalado 2010), and this may have contributed, along with government's support to agroecology, to the rise of research in agroecology.

In the case of Brazil, Wezel et al. (2009) also mention the role social movements have played in the spread of agroecological practices and in its recognition as a science. This, along with the existence of a myriad of reasons that range
Fig. 2 Distribution of publications according to study area

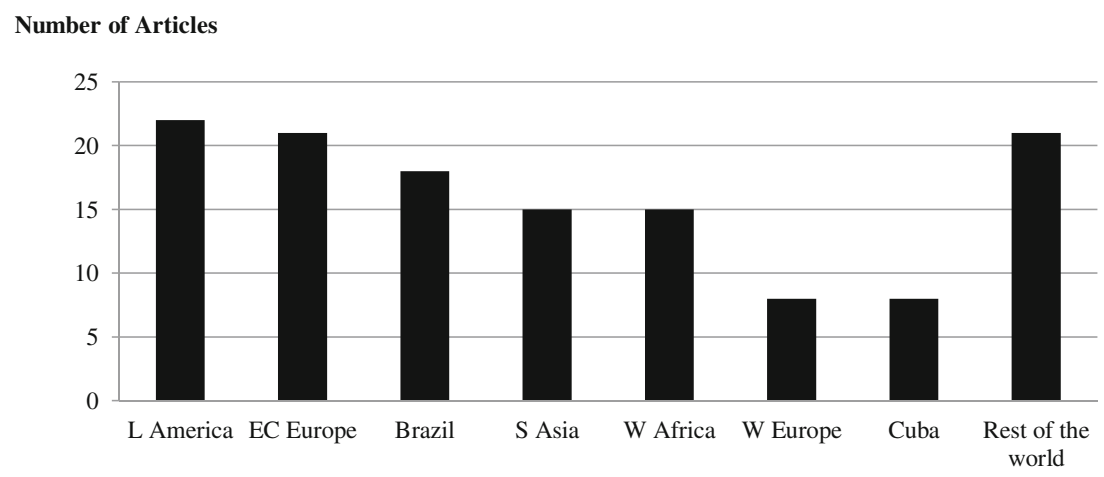

Regions where studies were conducted 
Fig. 3 Location of institutions which researchers are affiliated to, organized by region
Number of Articles

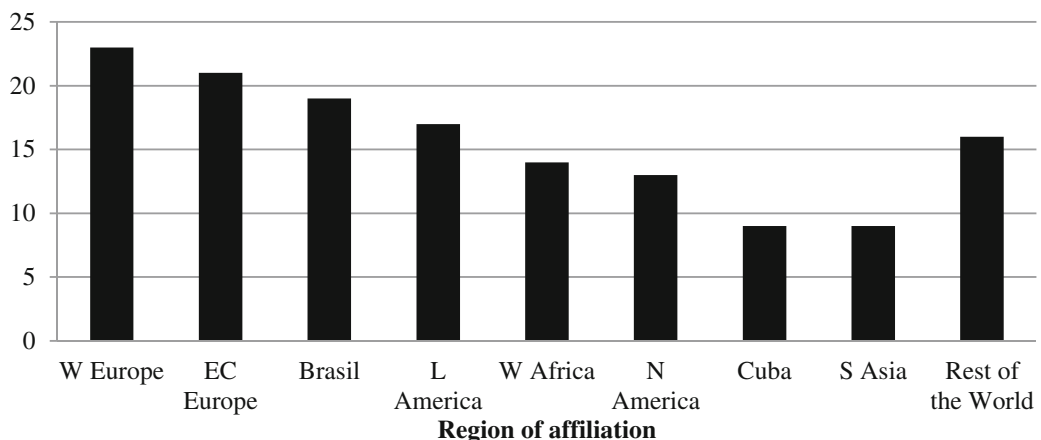

from economical and health to ideological and ethical issues, as pointed out by Brandenburg (2002), may explain the endorsement of agroecology by certain sectors in Brazil but does not explain the prominence of the country in global databases, especially when it comes to publications.

Nigeria, a country with almost as many researchers and studies as Cuba, is noticeable due to the presence of nonAfrican researchers working for international institutions according to Wezel and Soldat (2009). Although neither these authors nor us can provide clear information about researchers' nationalities, our findings confirm that most of articles comprised authors affiliated to international institutions (seven out of eight), and some (two) included researchers affiliated to non-African universities. This conforms to surveys which say that more than half of the sources of research funds in West Africa come from international organizations (UNESCO 2005). Nevertheless, there is a significant presence of researchers working for Nigerian universities (five articles) that should not be dismissed.

These asymmetries coincide with a pattern of coloniality of knowledge. Coloniality of knowledge is an analytical category proposed by subaltern studies that aims at explaining the endurance of hierarchies in production of knowledge, which refers to practices that maintain systems of thought that render inferiority to social groups in function of race and geopolitical origin (Maldonado-Torres 2007). Seen by region, dynamics in the production of knowledge in agroecology shows a clear difference in the role industrialized-North America and Western Europe - countries and non-industrialized countries-former and current colonies and communist countries-play. Industrialized countries produce global publications and global researchers but are not study areas. Conversely, non-industrialized countries are global study areas but local publishers and researchers. As a result, publishing flows unidirectionally from south to north but researchers flow in the opposite direction-following longstanding modern constructions of nature and progress where agroecosystems are entities closer to nature and hence more likely to be in the south. Thus, the south is more likely to play the researcher and researched roles and the north the researcher and the publishing ones, and if the south plays a publishing role, it does it in a local context without a strong global impact. Consequently, researchers or publishing do not flow between non-industrialized countries-i.e., scholars from Latin America do not do researches or publish in Asia or eastern and central Europe and vice versa. For instance, the Netherlands is the country that publishes the most (26 out 131 articles) even though there is only one research that was exclusively conducted in Dutch areas. One the contrary, Nigeria is one of the countries with more researchers and
Fig. 4 Regions where articles were published

\section{Number of Articles}

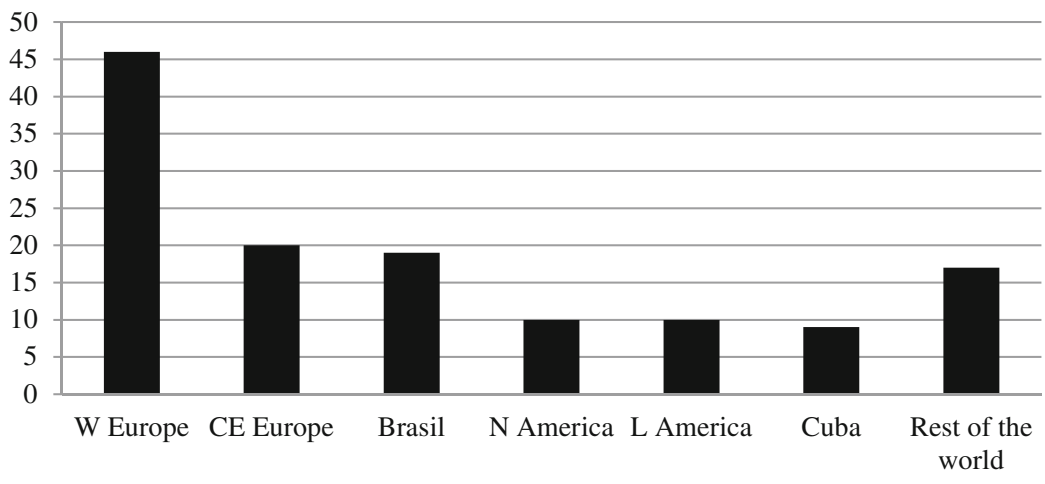

Publishing Regions 
Fig. 5 Frequency of publication in Spanish, English, Portuguese, or two of these languages
Number of Articles

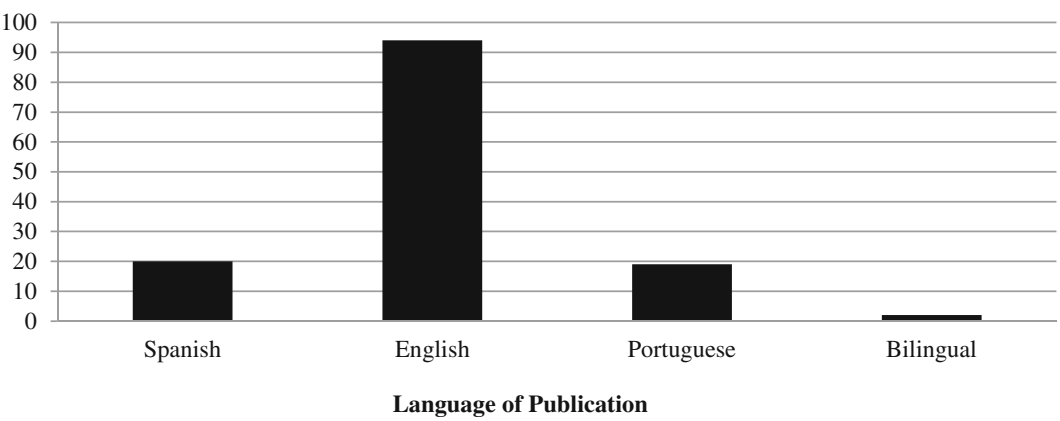

research studies but has not published a single article that has been referenced in the databases selected.

Coloniality of knowledge is a complex and wide issue and further studies are needed. For instance, studies in publication policies may help explain asymmetries in publication areas and languages found in the present paper. Also, regional databases - e.g., Scielo in Latin America or Indian Journals in South Asia-as international journals with independent website such as Leisa need to be studied in order to corroborate this hypothesis.

Nonetheless, coloniality of knowledge in agroecological research is not as striking as it was in the beginning of anthropology when all research studies were carried out in non-Western countries by Western-mostly male-scientists (García 2010). For reasons mentioned above, Brazil and Cuba lead empirical research and publication in Latin America. While Brazil published 19 articles, the rest of Latin America issued almost as many (ten) as Cuba alone (nine). However, it is a significant region in empirical agroecological research, being the most studied (22 out of 131 articles), and the forth with more researchers main-authoring papers, although this is concentrated in a few countries.

As a region, eastern and central Europe is, along with Brazil and Cuba, the most active area in agroecological empirical research (Figs. 2, 3, and 4). It is responsible for $16 \%$ of study areas, $15 \%$ of publications, and $18 \%$ of articles collected comprising authors affiliated to this region. Yet again, publications are domestic not involving studies conducted in other regions by researchers affiliated to countries from other areas. Other agroecology "hotspots" are Western Africa and South Asia, where not only Nigeria or Bangladesh are home to researchers and studies, although the former publishes in Western Europe and the latter only issues domestic research.

The findings in the present study differ in some aspects from Wezel and Soldat (2009). For instance, they place the USA as the country with more research studies followed by Western European countries and they put Nigeria, China, India, and Brazil as the "new "agroecology countries"" (2009, p. 12). Also, Wezel and Soldat found prolific authors like Altieri and Francis, while we discovered a very scattered practice with no particular remarkable empirical researchers. Divergence may arise from several reasons. First is the material selected. Wezel and Soldat reviewed all sorts of papers and books while we collected only empirical research articles. Thus, there was a boost of productive authors working for North American institutions in Wezel and Soldat's review. As they wrote, "the USA still dominates the publication rate, partly due to the many publications of Altieri, Francis and Gliessman" (2009, p. 12), but, according to our findings, these authors are mainly theoretical. As a result, the USA did not arise as the most noticeable country.

The second reason is the data selected. We did not include articles prior to 1990. Therefore, traditional authors like Bensin of Tischler who were customary in Wezel and Soldat's research did not appear in our searches. However, this is an irrelevant factor for our purpose of analyzing empirical research in the geopolitical context of global databases. As Wezel and Soldat (2009) show, publications before 1990 were scarce and many of them were books.

The third reason is the search places. While Wezel and Soldat used Scopus, Scholar Google, and the Virtual Catalogue of the University of Karlsruhe, we used databases that were also repositories, except for AGRIS. The inclusion of the latter might explain why eastern and central Europe came up as a "hotspot" in agroecological empirical research in the present study while it was practically invisible in Wezel and Soldat. The divergence of choice of search places may also explain to some extent the notoriety of China and India as agroecology countries in Wezel and Soldat's research while in ours Bangladesh turned out to be more active than India in South Asia and China was irrelevant. However, the most popular scientific journals for publication reported by Wezel and Soldat were contained in the databases selected for our study, yet there were divergences on this aspect as well. Both studies coincide in Agriculture, Ecosystems and Environment as the journal with more articles and include Eurasian Soil Science as another popular journal, but Wezel and Soldat's does not mention Ciência Rural as a common journal while ours does. Besides, Wezel and Soldat place ecology journals as one of the most appealing while we did not find them particularly relevant in agroecological empirical research. 
The fourth reason is relevant authors. Wezel and Soldat found authors with a significant number of publications in agroecology. Conversely, we found that the researchers who have main authored the most have published three articles. Divergences arise because the main publishing authors mentioned by Wezel and Soldat are either researchers who published before 1990-Bensin and Tischler-or scholars who have focused in theoretical aspects-Altieri, Gliessman, Francis, Dalgaard. This shows that empirical research in agroecology is carried by nonexperts in this field, something that is supported by Wezel and Soldat who state that most of the authors do not exceed three articles.

The fifth reason is topic distribution. While Wezel and Soldat found that there have been a significant amount of publications dealing with sustainability, sustainable agriculture, and sustainable development since 1990, we found that sustainability is not a prominent concern in empirical research. Similarly, the importance these authors give to the new definition of agroecology which takes a food systems approach is not reflected in empirical research. As we wrote before, we did not find a single empirical research committed to this issue.

\section{Conclusions}

It cannot be denied that agroecology has become a noticeable discipline as review articles and quantitative analyses have reported. Nonetheless, it seems to be a divergence between the way agroecology has been theoretically defined and what some empirical researchers are studying. On one hand, while theoretically agroecology has explicitly stated that it is a systemic, multidisciplinary approach either to sustainability in agroecosystems or food systems, many empirical researchers keep on taking mainstream analytical approaches that split the complex phenomenon of sustainability into more familiar "objects" such as soils, singular agroecological practices, and behavior of a monoculture/ species. This may be the result of formal training in analytic and disciplinary research instead of systemic or transdisciplinary, but it is important that these assessments continue in order to put into practice the approaches that agroecology has developed theoretically because they really aim at sustainability, a phenomenon that has to be studied systemically. Similarly, animal production has not been integrated into agroecological production yet. Although there are several articles that relate livestock to agroecological systems or agroecological practices, they are still in small amount (seven) compared to the number of papers studied (115).

There are several hotspots of agroecology, being Latin America and eastern and central Europe the most prominent. Nonetheless, colonial patterns in the production, distribution, and acquirement of knowledge are still present in this science. This may be a result of the current dynamics of science in a globalized world, but they help reproducing global hierarchical structures that have played a pivotal role in the underdevelopment of non-Western countries, and thus researchers concerned with development may find analytical categories such as coloniality of knowledge, of power, and of being as useful methodological and theoretical tools to assess and analyze food systems, development, agriculture, empowerment, and access and production of knowledge. Furthermore, agroecology's awareness of local knowledge, of the need of using participative methodologies and taking a systemic approach that recognizes the links and relations between different phenomena - e.g., cultural, economic, social, and agriculture - is a valuable element that may contribute to a real shift in the dynamics of global production of knowledge.

Acknowledgments We thank all authors and journals who replied and sent us their articles.

\section{References}

Altieri MA (2010) El estado del arte de la agroecología: revisando avances y desafíos. In: León T, Altieri MA (eds) Vertientes del pensamiento agroecológico: fundamentos y aplicaciones. Universidad Nacional de Colombia, Bogotá, pp 77-104

Altieri MA, Yurjevic A (1991) La agroecología y el desarrollo rural sostenible en América Latina. Agroecol Desarro 1:25-36

Brandenburg A (2002) Movimento agroecológico: trajetória, contradições e perspectivas. Desenvolv Meio Ambiente 6:11-28

Caporal FR (2006) Documenting agroecology: a competition in Brazil. LEISA 22:20-21

Dalgaard T, Hutchings NJ, Porter JR (2003) Agroecology, scaling and interdisciplinarity. Agric Ecosyst Environ 100:39-51. doi:10.1016/S0167-8809(03)00152-X

Francis C, Lieblein G, Gliessman S, Breland TA, Creamer N, Harwood R, Salomonsson L, Helenius J, Rickerl D, Salvador R, Wiedenhoeft M, Simmons S, Allen P, Altieri M, Flora C, Poincelot R (2003) Agroecology: the ecology of food systems. J Sustain Agric 22:99-118. doi:10.1300/J064v22n03 10

Funes-Monzote F (2001) La agricultura cubana en camino a la sostenibilidad. LEISA 7:21-23

García H (2010) Una historia de nuestros otros. Indígenas, letrados y antropólogos en el estudio de la diferencia cultural en Colombia (1880-1960). Universidad de los Andes, Bogotá

González M (1992) Agroecología: bases teóricas para una historia agraria alternativa. Agroecol Desarro 4:22-33

Haraway DJ (1989) Primate visions: gender, race, and nature in the world of modern science. Routledge, New York

Hecht SB (1995) The evolution of agroecological thought. In: Altieri MA (ed) Agroecology: the science of sustainable agriculture. Westview, Boulder, pp 1-19

Maldonado-Torres N (2007) Sobre la colonialidad del ser: contribnuciones al desarrollo de un concepto. In: Castro-Gómez S, Grosofoguel R (eds) El giro decolonial. Siglo del Hombre, Bogotá, pp 127-167

Meis L, Velloso A, Lannes D, Carmo MS, Cd M (2003) The growing competition in Brazilian science: rites of passage, stress and burnout. Braz J Med Biol Res 36:1135-1141 
Mendiola I (2009) La bio(tanato)política moderna y la producción de disponibilidad. In: Mendiola I (ed) Rastros y rostros de la biopolítica. Anthropos, Barcelona, pp 33-69

Midgley G (1993) Systems thinking and ecology. Syst Pract Action Res 6:565-566. doi:10.1007/BF01059513

Ortiz R (2009) La supremacía del inglés en las ciencias sociales. Siglo Veintiuno, Buenos Aires

Pai M, McCulloch M, Gorman JD, Pai N, Enanoria W, Kennedy G, Tharyan P, Colford JM Jr (2004) Systematic reviews and metaanalyses: an illustrated, step-by-step guide. Natl Med J India 17:86-95

Pereira RI (2008) Agroecología. Una necesidad urgente para la sostenibilidad de la vida humana en la tierra. Nuevos Tiempos 13:77-86

Regalado A (2010) Brazilian science: riding a gusher. Science 330:1306-1312. doi:10.1126/science.330.6009.1306

Sevilla E (2006) De la sociología rural a la agroecología. Icaria, Barcelona
Simeón RE (1997) La ciencia y la tecnología en Cuba. Rev Cubana Med Trop 4:153-160

Tomich TP, Brodt S, Ferris H, Galt R, Horwath WR, Kebreab E, Leveau JHJ, Liptzin D, Lubell M, Merel P, Michelmore R, Rosenstock T, Scow K, Six J, Williams N, Yang L (2011) Agroecology: a review from a global-change perspective. Annu Rev Environ Resour 36:193-222. doi:10.1146/annurevenviron-012110-121302

UNESCO (2005) UNESCO scientific report 2005. UNESCO, Paris

Wezel A, Soldat V (2009) A quantitative and qualitative historical analysis of the scientific discipline of agroecology. Int $\mathrm{J}$ Agric Sustain 7:3-18. doi:10.3763/ijas.2009.0400

Wezel A, Bellon S, Doré T, Francis C, Vallod D, David C (2009) Agroecology as a science, a movement and a practice. A review. Agron Sustain Dev 29:503-515. doi:10.1051/agro/2009004 